\title{
Effects of coriander, thyme, vanadyl and tungstate on some biochemical parameters in broiler chickens
}

\author{
F.Kh. Tawfeek and N.G. Mustafa
}

Department of Physiology, Biochemistry \& Pharmacology, College of Veterinary Medicine, University of Mosul, Mosul, Iraq

\begin{abstract}
In the present study we evaluate the effect of two doses of Coriander (Coriandrum sativum), Thyme (Thymus vulgaris), Vanadyl sulfate, and Sodium tungstate on liver glycogen concentration (LGC), serum enzymes Alanine transaminase (ALT) and Aspartate transaminase (AST) levels in 15 days age broiler chickens. The results showed that full dose of Coriander (1500 $\mathrm{mg} / \mathrm{kg} \mathrm{Bwt})$ has a significant $(\mathrm{P} \leq 0.05)$ decreasing effect on LGC, ALT and AST levels, in reverse to half dose which do not show a significant effect. In the combination of the half dose of Coriander with Sodium tungstate $(750 \mathrm{mg} / \mathrm{kg} \mathrm{Bwt}+15 \mathrm{mg} / \mathrm{kg}$ Bwt) there is a significant increase in LGC and ALT, but not AST level in comparing with control group. Also the same effects were seen in combination dose of Coriander with Vanadyl sulfate $(750 \mathrm{mg} / \mathrm{kg} \mathrm{Bwt}+50 \mathrm{mg} / \mathrm{kg} \mathrm{Bwt})$ on the studied parameters. On the other hand, results show that Thyme in full dose $(2000 \mathrm{mg} / \mathrm{kg}$ Bwt $)$ has similar significant effect by lowering LGC, ALT, and AST levels as in case of Coriander, while half dose $(1000 \mathrm{mg} / \mathrm{kg} \mathrm{Bwt})$ of Thyme show no significant effects on the studied parameters. Thyme with Vanadyl sulfate have no significant effect on ALT and AST with increasing LGC. Sodium tungstate in the full dose $(30 \mathrm{mg} / \mathrm{kg}$ Bwt) has a significant decline effect on the studied parameters in comparing with control group, while there is no effect of Sodium tungstate when used in half dose $(15 \mathrm{mg} / \mathrm{kg} \mathrm{Bwt})$ except increasing level of ALT. Vanadyl sulfate has the same effect similar to Sodium tungstate in full doses, while half dose of Vanadyl sulfate show no significant effect on studied parameters. From this study we conclude that both medicinal plants Coriander and Thyme also Sodium tungstate and Vanadyl sulfate have a significant dose dependant effects on glycogen concentration and serum levels of ALT and AST in broiler chickens.
\end{abstract}

Keywords: Coriander; Thyme; Vanadyl sulfate; Sodium tungstate; Liver enzymes; Glycogen Available online at http://www.vetmedmosul.org/ijvs

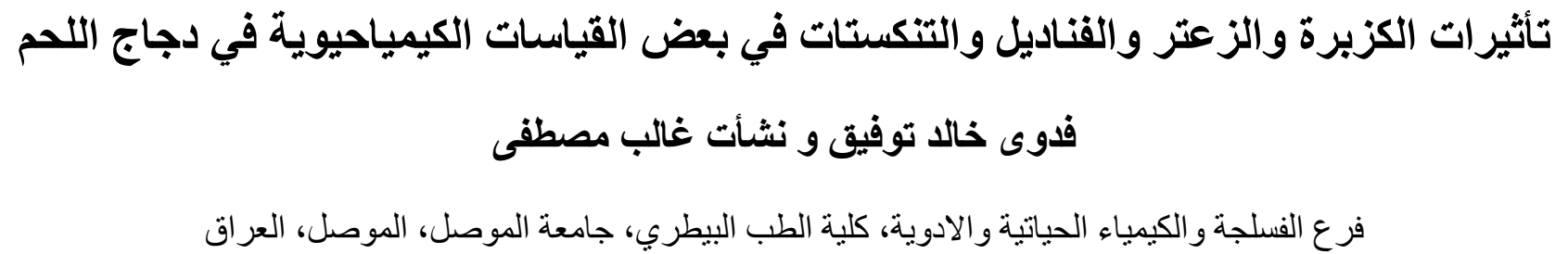

تم إجر اء الدر اسة الحالية لمعرفة تأثثر جر عتين من كل من: نبات الكزبرة (Coriandum sativum) نبات الزعتر كتر (Thymus vulgaris)، كبريتات الفاناديل، وتتكستات الصوديوم على تركيز الكلايكوجين في كبد فروج اللحم بعدر 21 يوم وكذللك مستوى انزيمي الالانين ترانس

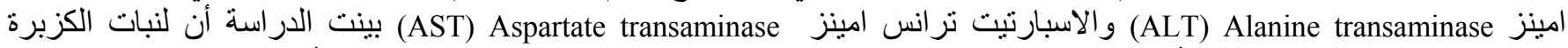

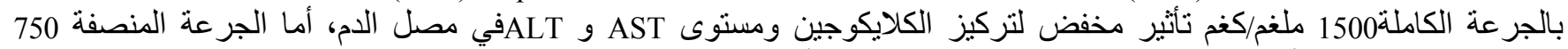

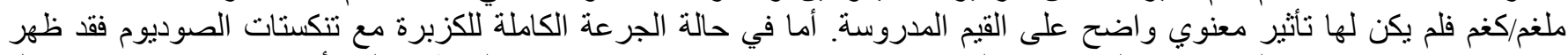

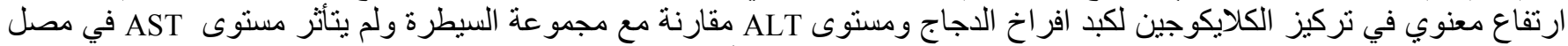

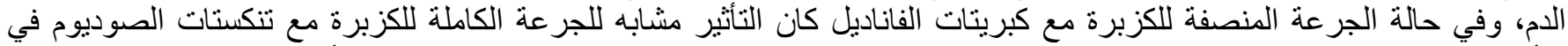

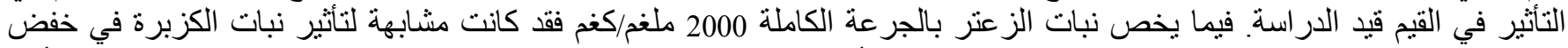

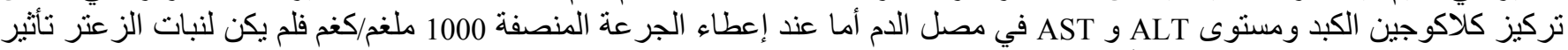
معنوي على القيم الثلاث قيد الدر اسة. أما الجر عة المنصفة للزئ عنر مع تنكستات الصوديوم فقد رفعت من مستوى ALT بشكل معنوي، بينما 


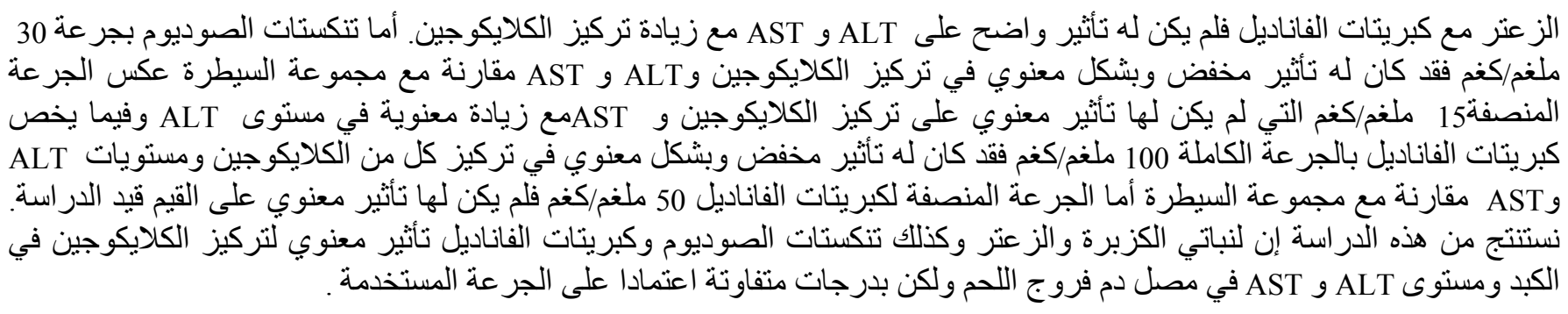

\section{Introduction}

Coriander (Cariandrum sativum) medicinally used in drug preparation as carminative, gastrotonic, antispasmodic, aphrodisiac, and hypoglycemic $(1,2)$. However, coriander contain $1.8 \%$ volatile oil (consisting of $65-70 \%$ linalol "coriandrol" small quantity of $\alpha$-pinene, $\gamma-$ trepinen, limonene, P-cymene, non-linalol alcohol, and esters (3), aqueous extract of coriander stimulate insulin excretion from $\beta$-cell of pancreas, which may be due to its insulin mimetic effect or action as releasing factor, or posses insulin like action (4) coriander seeds has significant decreasing effect on total cholesterol and triglycerides in laboratory animal, which may by due to increase in activity of $\beta$-hydroxymethylglutaryl-CoA reductase and increase activity of plasma lecithine cholesterol acyl transferase (5). Thyme (Thymus vulgaris) was used as carminative, antirheumatic, and in certain skin disease treatment $(6,7)$ also its used as antiparastic, analgesic, hypotensive agent (8), thyme contain volatile oil (consisting of $55 \%$ phenols) themol and carvacral (9) also contain thymine (7), numerous types of flavonoids $(10,11)$ and vitamine $\mathrm{E}(10)$, physiological and biochemical effect of the thyme was studied by many researchers, they show that thyme cause hypoglycemia and increase in appetite, also significant decrease in total cholesterol and triglycerides levels (12). Also thyme contain bifunctional inducers (i.e : substances capable of inducing both phase I and phase II enzymes) phase I enzymes: xenobiotic-metabolizing enzymes such as 7-ethoxycoumarin O- decthylase (ECOD), phase II enzymes; glutathione S- transferase (GST) and quinone reductase (QR) (13). Certain authors show that sodium tungstate correct hypoglycemia in both type I and type II diabetes mellitus $(14,15)$ sodium tungstate increase the activity of many enzymes as: glucokinase, 6- phosphofructo 2-kinase, and pyruvate kinase, and depress the activity of phosphoenol pyruvate carboxy kinase in the liver of diabetic rats, all these changes lead to decrease in the blood glucose level by increasing levels of glycogen, glucose 6phosphate and fructose 2.6-bisphosphate (15). On the other hand, it was documented that vanadium has an insulin mimetic effect on target tissues (liver, adipose tissue, and skeletal muscle), in addition most mammalian cells contain vanadium in very trace amounts (about $20 \mathrm{nmol}$ ) inside the body vanadium act as enzyme inhibitor to $\mathrm{Na}^{+}-\mathrm{K}^{+}$ATPase and another phosphorylases (16), in muscle and liver of normal laboratory animal (rat) vanadium lead to increase glucose uptake $(17,18)$. Glycogen a storage form of carbohydrate in vertebrates, it synthesized by glycogenesis when glucose levels are high and degraded by glycogenolysis when glucose is in short supply, both glycogenesis and glycogenolysis controlled primarily by interplay between two hormones: insulin and glucagon $(19,20)$. Alanine transaminase (ALT) (previously called glutamate pyruvate transaminase GTP) present in high concentration In liver and to less extent in skeletal muscle, kidney, and heart (20), Aspartate transaminase (AST) (previously called glutamate oxaloacetate transaminase GOT) present in high concentration in cells of cardiac and skeletal muscle, liver, kidney, RBC, and damage to any of these tissues can cause increase in plasma AST level (21).

\section{Materials and methods}

\section{Animals and experimental design}

One hundred forty four Fabrow broiler chickens in the age of 1 days were used in this experiment, these chickens kept in aluminum made cages (dimension of 100X70X46 $\mathrm{cm})$ at the house of animal/College of Veterinary Medicine/University of Mosul, and fed on concentrated diet (the composition of diet as follow (\%): corn 54.3, barn 15, soya bean 27 , calcium 0.7 , vadenamix 3 ) chickens housed under the same suitable conditions: temperature of $35^{\circ} \mathrm{C}$, lighting of $24 \mathrm{hr}$, well ventilation and humidity, diet and water ad libitum. At the age of 15 days chickens divided into three major groups, each major group was subdivided into 5 subgroups each one contain 6-15 chickens, as shown in the following tables: 
Table 1: Group 1 (38 chickens).

\begin{tabular}{lccc}
\hline Treatment & Dose & Duration of treatment & No. of chickens \\
\hline Control (distilled water) & $1 \mathrm{ml}$ & 2 weeks & 6 \\
Coriandrum sativum & $750 \mathrm{mg} / \mathrm{kg} \mathrm{Bwt}$ & 2 weeks & 8 \\
Thymus vulgaris & $1000 \mathrm{mg} / \mathrm{kg} \mathrm{Bwt}$ & 2 weeks & 8 \\
Sodium tungstate & $15 \mathrm{mg} / \mathrm{kg} \mathrm{Bwt}$ & 2 weeks & 10 \\
Vanadyl sulfate & $50 \mathrm{mg} / \mathrm{kg} \mathrm{Bwt}$ & 2 weeks & 6 \\
\hline
\end{tabular}

Table 2: Group 2 (38 chickens).

\begin{tabular}{lccc}
\hline Treatment & Dose & Duration of treatment & No. of chickens \\
\hline Control (distilled water) & $1 \mathrm{ml}$ & 2 weeks & 6 \\
Coriandrum sativum & $1500 \mathrm{mg} / \mathrm{kg} \mathrm{Bwt}$ & 2 weeks & 8 \\
Thymus vulgaris & $2000 \mathrm{mg} / \mathrm{kg} \mathrm{Bwt}$ & 2 weeks & 8 \\
Sodium tungstate & $30 \mathrm{mg} / \mathrm{kg} \mathrm{Bwt}$ & 2 weeks & 10 \\
Vanadyl sulfate & $100 \mathrm{mg} / \mathrm{kg} \mathrm{Bwt}$ & 2 weeks & 6 \\
\hline
\end{tabular}

Table 3: Group 3 (68 chickens).

\begin{tabular}{lccc}
\hline Treatment & Dose & Duration of treatment & No. of chickens \\
\hline Control (distilled water) & $1 \mathrm{ml}$ & 1 week* & 8 \\
Coriander + Sodium tungstate & $(750+15) \mathrm{mg} / \mathrm{kg} \mathrm{Bwt}$ & 1 week $^{*}$ & 15 \\
Coriander + Vanadyl sulfate & $(750+50) \mathrm{mg} / \mathrm{kg} \mathrm{Bwt}$ & 1 week* & 15 \\
Thyme + Sodium tungstate & $(1000+15) \mathrm{mg} / \mathrm{kgBwt}$ & 1 week* & 15 \\
Thyme + Vanadyl sulfate & $(1000+50) \mathrm{mg} / \mathrm{kg} \mathrm{Bwt}$ & 1 week* & 15 \\
\hline
\end{tabular}

* Treatment used for 1 week because of combination doses may be harm to chickens in this age

\section{Medicinal plants}

Two Medicinal plants were used Coriander (Coriandrum sativum) and Thyme (thymus vulgaris) obtained from local markets and processed by cleaning, sieving, crushing, boiling and saved after cooling at $-4{ }^{\circ} \mathrm{C}$ until use. Coriandrum sativum prepared by boiling $50 \mathrm{~g}$ in $50 \mathrm{ml}$ distilled water and treatment doses given as follows: $1500 \mathrm{mg} / \mathrm{kg}$ Bwt, $750 \mathrm{mg} / \mathrm{kg}$ Bwt, $750 \mathrm{mg} / \mathrm{kg}$ Bwt combination dose with either sodium tungstate or vanadyl sulfate. Thymus vulgaris also prepared by boiling $20 \mathrm{~g}$ in 50 $\mathrm{ml}$ distilled water and treatment doses given as follows: $2000 \mathrm{mg} / \mathrm{kg}$ Bwt, $1000 \mathrm{mg} / \mathrm{kg}$ Bwt, $1000 \mathrm{mg} / \mathrm{kg}$ Bwt combination dose with either sodium tungstate or vanadyl sulfate. Vanadyl sulfate solution prepared immediately before use by dissolving $2 \mathrm{~g}$ vanadyl sulfate (fluka $\mathrm{AG}$, Buchas SG, Switzerland) in $50 \mathrm{ml}$ distilled water. Sodium tungstate solution prepared immediately before use by dissolving $0.3 \mathrm{~g}$ and $0.6 \mathrm{~g}$ sodium tungstate, Riedel - De Hean AG seelze - Hannover, Germany) in $50 \mathrm{ml}$ distilled water.

All doses given orally by gavage needle and blood collected from wing vein at the end of the experiment, serum separated by blood centrifugation $(3000 \mathrm{~g})$ for 15 min, and finally serum stored at $-20^{\circ} \mathrm{C}$ until performing biochemical tests.

\section{Biochemical tests}

Glycogen concentration: liver glycogen concentration determined by using Anthron reagent according to the method of plummer (1987) (22).

AST: which was measured in serum using colorimetric method (22) by using kit (bioMerieux, France) at $505 \mathrm{~nm}$ wavelength and enzyme level expressed in $\mathrm{U} / \mathrm{L}$.

ALT: also was measured in serum using colorimetric method (23) by using kit (bioMerieux, France) at $505 \mathrm{~nm}$ wavelength and enzyme level expressed in $\mathrm{U} / \mathrm{L}$.

\section{Statistical analysis}

Result analysis done statistically using one way analysis of variance (ANOVA) and differences between groups determined by Duncan test, significant value mean $(\mathrm{P} \leq 0.05)$ (24).

\section{Results}

Form table (4) we were noted that glycogen concentration decrease significantly $(\mathrm{P} \leq 0.05)$ in full dose of coriander, vanadium, thyme and tungstate treated groups, in comparing with control value. The same table (4) show that all treatments lead to decline in liver enzymes ALT and AST. 
From table (5) we were observed that all treatments with the half doses failed to produce any significant effects $(\mathrm{P} \leq 0.05)$ on all the studied parameters (except increase in the level of ALT by sodium tungstate) when compared with control group. Table (6) show that the level of AST not affected significantly by different combination doses treatment in comparing with control value. Also the glycogen concentration (table 6) increase significantly with all treatments with exception of combination of Thyme with sodium tungstate.

Table 4: Effects of full doses of coriander, thyme, sodium tungstate, and vanadyl sulfate on ALT, AST levels, glycogen conc.

\begin{tabular}{lccc}
\hline Treatment & ALT U/L & AST U/L & Glycogen \\
\hline Control D.W orally & $24.8 \pm 3.37 \mathrm{a}$ & $148 \pm 5.40 \mathrm{a}$ & $22.4 \pm 2.01 \mathrm{a}$ \\
Coriandrum sativum $1500 \mathrm{mg} / \mathrm{kg} \mathrm{Bwt}$ & $11.2 \pm 0.27 \mathrm{~b}$ & $76.8 \pm 1.56 \mathrm{~b}$ & $8.1 \pm 0.92 \mathrm{c}$ \\
Thymus vulgaris $2000 \mathrm{mg} / \mathrm{kg} \mathrm{Bwt}$ & $5.49 \pm 0.84 \mathrm{~b}$ & $83.1 \pm 2.47 \mathrm{~b}$ & $15.4 \pm 2.4 \mathrm{~b}$ \\
Sodium tungstate $30 \mathrm{mg} / \mathrm{kg} \mathrm{Bwt}$ & $6 \pm 1.46 \mathrm{~b}$ & $77.6 \pm 4.04 \mathrm{~b}$ & $13.1 \pm 3.9 \mathrm{bc}$ \\
Vanadyl sulfate $100 \mathrm{mg} / \mathrm{kg} \mathrm{Bwt}$ & $6.67 \pm 1.5 \mathrm{~b}$ & $72 \pm 3.03 \mathrm{~b}$ & $6.9 \pm 1.0 \mathrm{c}$ \\
\hline
\end{tabular}

Values were expressed as Mean \pm SE, Values with different letters are significantly different at $(\mathrm{P} \leq 0.05)$.

Table 5: Effects of half doses of coriander, thyme, sodium tungstate, and vanadyl sulfate on ALT, AST levels, glycogen conc.

\begin{tabular}{lccc}
\hline Treatment & ALT U/L & AST U/L & Glycogen \\
\hline Control D.W orally & $13.8 \pm 0.72 \mathrm{~b}$ & $101.8 \pm 5.4 \mathrm{a}$ & $18.3 \pm 5.7 \mathrm{a}$ \\
Coriandrum sativum $750 \mathrm{mg} / \mathrm{kg}$ Bwt & $14.7 \pm 0.94 \mathrm{a} \mathrm{b}$ & $104.5 \pm 1.7 \mathrm{a}$ & $10.4 \pm 1.7 \mathrm{a}$ \\
Thymus vulgaris $1000 \mathrm{mg} / \mathrm{kg} \mathrm{Bwt}$ & $13.6 \pm 0.53 \mathrm{~b}$ & $92.7 \pm 2.7 \mathrm{a}$ & $10.9 \pm 2.3 \mathrm{a}$ \\
Sodium tungstate $15 \mathrm{mg} / \mathrm{kg} \mathrm{Bwt}$ & $17.4 \pm 1.0 \mathrm{a}$ & $100.5 \pm 4.7 \mathrm{a}$ & $11 \pm 2.3 \mathrm{a}$ \\
Vanadyl sulfate $50 \mathrm{mg} / \mathrm{kg} \mathrm{Bwt}$ & $12.2 \pm 1.5 \mathrm{~b}$ & $102.1 \pm 8.4 \mathrm{a}$ & $14.2 \pm 2.3 \mathrm{a}$ \\
\hline
\end{tabular}

Values were expressed as Mean \pm SE, Values with different letters are significantly different at $(\mathrm{P} \leq 0.05)$.

Table 6: effects of half doses interaction of coriander, thyme, sodium tungstate, and vanadyl sulfate on ALT, AST levels, glycogen conc.

\begin{tabular}{lccc}
\hline Treatment & ALT U/L & AST U/L & Glycogen \\
\hline $\begin{array}{l}\text { Control D.W orally } \\
\text { Coriandrum sativum } 750 \mathrm{mg} / \mathrm{kg} \text { Bwt and }\end{array}$ & $12.6 \pm 0.47 \mathrm{c}$ & $95.4 \pm 3.2 \mathrm{a}$ & $13.9 \pm 1.2 \mathrm{c}$ \\
$\begin{array}{l}\text { Sodium tungstate } 15 \mathrm{mg} / \mathrm{kg} \mathrm{Bwt} \\
\text { Coriandrum sativum } 750 \mathrm{mg} / \mathrm{kg} \text { Bwt and }\end{array}$ & $17.6 \pm 1.0 \mathrm{ab}$ & $100.9 \pm 1.7 \mathrm{a}$ & $30.9 \pm 3.02 \mathrm{a}$ \\
$\begin{array}{l}\text { Vanadyl sulfate } 50 \mathrm{mg} / \mathrm{kg} \mathrm{Bwt} \\
\text { Thymus vulgaris } 1000 \mathrm{mg} / \mathrm{kg} \text { Bwt and }\end{array}$ & $18.5 \pm 1.06 \mathrm{a}$ & $87.5 \pm 9.7 \mathrm{a}$ & $26.3 \pm 2.2 \mathrm{ab}$ \\
$\begin{array}{l}\text { Sodium tungstate } 15 \mathrm{mg} / \mathrm{kg} \mathrm{Bwt} \\
\text { Thymus vulgaris } 1000 \mathrm{mg} / \mathrm{kg} \text { Bwt and }\end{array}$ & $14.5 \pm 1.45 \mathrm{bc}$ & $94.4 \pm 3.06 \mathrm{a}$ & $9.1 \pm 0.51 \mathrm{c}$ \\
Vanadyl sulfate $50 \mathrm{mg} / \mathrm{kg} \mathrm{Bwt}$ & $90.97 \pm 3.48 \mathrm{a}$ & $23.2 \pm 1.42 \mathrm{~b}$ \\
\hline
\end{tabular}

Values were expressed as Mean \pm SE, Values with different letters are significantly different at $(\mathrm{P} \leq 0.05)$.

\section{Discussion}

The decrease in liver glycogen concentration caused by coriandrum may be caused by enhancing glucose transport and glucose oxidation (4) also it may be decrease the activity of key enzymes in glycogenesis (glycogen synthetase), while vanadium decreasing of glycogen concentration conceides to results of (25) and its act by its insulin mimetic effects through altering the properties of insulin receptors or at same post receptor level or both (25) in both normal and diabetic laboratory animals.

There are no clear previous results about the effect of thyme on glycogen concentration but it may be due to the effect of one of its components as: carphecral $86.3 \%$ (26) or Gamma-terpinene synthase and menotrepene cyclase enzymes (26), on the other hand some researchers refer to the antidiabetic and insulin like effect of tungstate (27) while other scientists (15) mention that tungstate did not modify hepatic glycogen concentration either in healthy or diabetic animals, tungstate act on liver by increase activity of enzyme glucokinase, 6- phosphofracto 2-kinase and pyruvate kinase also decrease activity of phosphoenol pyruvate carboxy kinase (14) all these effects may be lead to decreasing in the glycogen concentration these variations may be due to difference in doses administered or may be due to differences in response to these plants extract 
between chickens and other laboratory animals (mice and rat). We don't have enough references about the effect of coriander or thyme on ALT and AST and our work may be the first one in this direction, however, our explanation based on the effects of one or more components of coriander and thyme on ALT and AST, in coriander as : $(\gamma-$ trepinen, P-cymene, coumarins) (28) and in thyme as: thymol, flavonoids, phenols) (28), but this needs further investigations and work. all treatments with the half doses failed to produce any significant effects on the studied parameters (except increase the level of ALT by sodium tungstate), and this may be due to the half doses are not enough to produce the effect caused by the full doses, while the most acceptable explanation to the effect of tungstate in high dose, that cause certain liver damage. On the other hand the combined treatment doses of coriander and sodium tungstate the most affected treatment in electing liver glycogen concentration followed by combined treatment doses of coriander and vanadyl sulfate in that effect and this may be due to synergistic effect of combination treatment of coriander with sodium tungstate and also with vanadyl sulfate, also we don't have enough references about the details of these synergistic effects. The level of AST not clearly affected by different combination doses treatment in comparing with the changes in ALT, and this may be due to that AST level most expressive to affections of cardiac and skeletal muscle (21) while ALT level reveal effect on liver and then skeletal muscle, kidney, and to less extent cardiac muscle (21).

From this study we conclude that coriander, thyme, sodium tungstate, and vanadyl sulfate have a significant effects but differ according to the dose on glycogen concentration and serum levels of ALT and AST in broiler chickens.

\section{Acknowledgement}

Authors thank the College of Veterinary Medicine, University of Mosul for supporting this study.

\section{References}

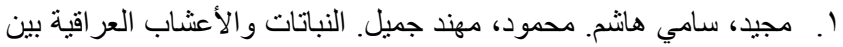

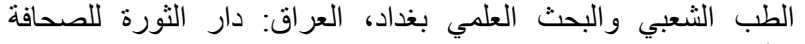

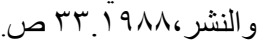

2. Hussein FTK. Medical plants of Libya, 1st ed. Libya:" Arab Encyclopedia House" ; 1985.348p

3. Evans WC. Trease and Evans Pharmacognosy. $14^{\text {th }}$ ed. W.B. Saunders Company Ltd, USA;1997.122p.

4. Gray AM, Flatt R. Insulin releasing and insulin-like activity of the traditional anti-diabetic plant Coriandrum sativum (coriander) $\mathrm{Br} \mathrm{J}$ Nut.1999;81: 203-209

5. Chithra V, Leclamma S. Hypolipidemic effect of coriander seeds (Coriandrum sativum): mechanism of action. Plant Food Hum Nut.1997; 51: 167-173.
6. Cheij R. McDonal Encyclopedia of medicinal plants. McDonal and Co. (publishers) London;1984. 209,309,313p.

7. Mossa JS. Medicinal plants of Saudi Arabia, Pub. By king Saudi university libraries, Riyadh;1987.244p.

8. Guseinov DIA, Kagramanov KM, Kasumov FIU, Akhundov RA. Research on the chemical composition and aspects of the pharmacological action of the essential oil of Kochi thyme (thymes kotschyanus Boiss.) Farmak Toksikol.1987;50:73-74.

9. Schwarz K, Ernst H, Ternes W. Evaluation of antioxidative constituents from thyme. J Sci food Agric.1996;70: 217-233.

10. Guillen MD, Manzanoz MJ. Study of the composition of the different parts of a Spanish thymus vulgaris L. Plant Food Chem.1998;63:373383.

11. Wang M, Li J, Ho GS, Peng X, Ho CT. Isolation and identification of antioxidative flavonoid glycosides from thyme (Thymes valgaris $L$.) $\mathrm{J}$ food lipids.1998;5:313-321.

Y 1. النعيمي، سعد محمد علي. تأثنير بعض النباتات المخفضة لكلوكوز الدم في

بعض الصفات الفسلجية والكيميائية الحياتية ومعامل التحويل التيلية الغذائي

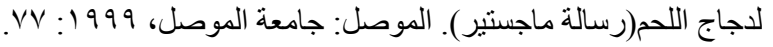

13. Sasaki K, wada K, Tanada Y, Yoshimura T, Matuoka K, Anno T. Thyme (Thymus valgaris) leaves and its constituents increase the activities of xenobiotic-metabolizing enzymes in mouse liver J Med Food.2005;8(2):184-189.

14. Barbera A, Rodriguez-Gil JE, Guinovart JJ. Insulin like action of tungstate in diabetic rate (normalization of hepatic glucose metabolism). J Biochem.1994;269: 20047-20053.

15. Barbera A, Frenandelez-Alvarez J, Truc A, Gomis R, Guinovart JJ. Effect of tungstate in neonatally streptozotocin-inducel diabetic rats: mechanism leading to normalization of glycemia. Diabetologia.1997;40:143-149.

16. Sun Q, Sekar N, Goldwaser I, Gershonov E, Fridkin M, Shectter Y. Vanadate restores glucose -6- phosphate in diabetic rats. A mechanism to enhance glucose metabolism. Endocrinol. Met. 2000;279:E403-E410.

17. Meyerouitch J, Farfel Z, Sack J, Schectter Y. Oral administration of vanadate normalizes blood glucose levels in streptozotocin-treated rats. Characterization and mode of action. J Biol Chem.1987;262: 6658-6662

18. Orvig C, Thompson KH, Battell M, McNeill J. Vanadium compound as insulin mimics. In: Metal ions in biological systems. Sigel H, Sigel A. (eds). Marcel Dekker, Inc. New York. 1995:575-494.

19. McKee T, McKee JR. Biochemistry. $1^{\text {st }}$ ed. WMC Brown pub; 1996.372p.

20. Ganong WF. Review of medical physiology. $13^{\text {th }}$ ed. Appleton and Lange Co;1987.455p.

21. Zilva JF, Pannal PR, Mayne PD. Clinical chemistry in diagnosis and treatment. $5^{\text {th }}$ ed. London. Edward Arnold; $1988.277 \mathrm{p}$.

22. Plummer DT. An introduction to practical Biochemistry. 3rd ed. U.K. McGraw-Hill book Co;1987.182-188.

23. Reitman S, Frankel S. A colorimetric method for the determination of serum glutamic oxaloacetic and glutamic pyruric transaminase. Am J Clin Path. 1957;28:56-63.

24. Steel RGD, Toorie JH. Principles and procedures of statistics. 2nd ed. New York. McGraw-Hill book Co;1980.78-80, 107-109, 125-127.

25. Khandelwal RL, Pugazhenthi S. In vivo effects of vanadate on hepatic glycogen metabolizing and lipogenic enzymes in insulin-dependent and insulin-resistant diabetic animals. Mol Cellul Biochem. 1995; $153: 87-94$

26. Giuseppe R, Daniela B. The essential oil of Sicilian Thymus capitatus L-Hoffmons et link. J Essent Oil Res. 1992;4:417-418.

27. Kletzin A, Adams MW. Tungsten in biological systems Microbiol Rev. 1996;18(1): 5-63.(Abstract)

28. Taylor L. The healing power of rainforest herbs. present by Raintree Nutrition, Inc., Carson City.2005; NV89701. 